\title{
Wanted: a science policy
}

Chris Sherwell reports on a European science policy symposium held in Brussels last week

Straitened economic circumstances concentrate the minds of policymakers wonderfully. The problems of those involved in science policy are worse than most, however, for the additional reason that, with science seemingly everywhere, science policy is seemingly nowhere. But with the research base an important pillar of support for the developed countries' economies, the need for science advice in government rightly remains undisputed, and the need to deal with problems with a scientific content is undiminished. So the search goes on.

As part of that search, the European Commission last week sponsored a three-day symposium at a fashionable hotel in Brussels. Ambitiously entitled "Strategies for Europe: Proposals for science and technology policies", it was organised by the private grouping known as the Science Policy Foundation, and attended by some sixty people drawn from research councils, research institutes, universities, industry and the media as well as governments.

It may remain the most important outcome of the meeting that the lines of thinking developed in recent years under the inspiration of the 'Europe $+30^{\prime}$ idea are at least being supplemented and that concern has begun to focus on more immediate problems. If so the involvement of the Science Policy Foundation could increase, although notable absentees from the meeting, particularly from Britain's science policy establishment, may mean that any transfer of legitimacy will take time. A former Director General at the Commission, Michael Shanks, suggested in drawing conclusions from the meeting that there ought to be an organisation of science policy federations whose work could be enriched through association without being subordinate to it, and that this possibility ought to be examined, perhaps by the Commission working with the Science Policy Foundation. There was a need, he said, for the Community to have a loose network of experts independent of political allegiances who could together provide advice on common problems for leaders lacking a science education and thus help to bridge the gap between them and the broad community they served.

To this end Directorate General
XII, the department of the Commission which with its responsibilities for research, science and education provided the crucial support for last week's symposium, is now engaged in preparing for two events. One is a three-day symposium which it is organising for June on the issues which the phrase "Science and Society" now commonly embraces. It is understood that this has met with resistance from some scientists and policy makers in certain member countries but has been welcomed by others. The Commission's view is guarded, but it appears prepared to see the issues given an airing under its auspices on pain of withdrawal if the experiment is as fruitless as its critics imply.

Preparations for the other event are less well finalised. It stems from the suggestion in February by Guido Brunner, the European Commissioner for both Energy and Research, of a forum or hearings on the issue of nuclear power. What form these might take remains unclear, but they are likely to be held after the proposed symposium on science and society. What is certain is that, in the aftermath of President Carter's recent announcement on nuclear power, the already strengthening worries of the Commission on the issue have been further reinforced. Faced with an increasingly threatened European nuclear programme and continuing troubles over uranium supplies from North America, the fact that Euratom and the IAEA have now agreed terms on safeguards seems to cut little ice, and this is a matter for some despair. The Carter statement confirms the difficulties of the Commission's own position: its first official response last week (the initiative will be "studied closely") was well muted.

If the symposium was anything to go by, on the science policy front it is now apparent that in Europe there is an emerging concern with two problems in particular. One is the effect of producing increasing numbers of highly qualified science graduates for whom the end of an era of university expansion has coincided with a period of inflation and recession to produce the grim spectre of unemployment The worry is not just about where the professors of future generations will come from, or about the more fundamental matter of the state of science and research; there is also the practical worry, outside the issue of ageing research staffs, of the sheer waste involved, the opportunities foregone.
For those who choose to ignore such central matters of how much a country should devote to basic research-an issue on which researchers are more and more being called upon to defend themselves-the obvious destination for graduates is industry. But industrial innovation is the other problem over which there appears to be emerging concern in Europe: how is manufacturing industry, the so-called engine of growth, to improve its capacity to generate and harness the process and impact of innovation?

One tangible achievement of the symposium may turn out to be that it encouraged the first steps towards some amelioration of these sorts of problems. On the matter of industrial innovation, for example, in which the Commission has for some time shown an interest, for instance through its so-called Brunner-D'Avignon task force, the prospect emerged of cooperation betwen the Commission and the European Industrial Research Management Association (EIRMA), possibly with the additional assistance of the Science Policy Foundation.

Inevitably the Community's main interest, being borne of shared economic interest, is likely to focus more readily on innovation in this fashion. But it does not confine itself to that, and the symposium also confirmed that the European body that has firmly established itself as the one best placed to answer questions about the overall state of basic research throughout the continent is the Strasbourg-based European Science Foundation (ESF), made up of research councils and academies from 45 member countries.

The European Commission has close links with the ESF, and now plainly recognises its authority to speak on matters of basic research. A keynote address from Dr Gunter Schuster, Director General at DGXII, helped the ESF's President, Sir Brian Flowers, to draw a positive response later to his own intimations that the Commission could assist in efforts to establish a fellowship scheme to help build a European social science and to develop the humanities-a goal which reflects the ESF's own desire to concern itself less with the English science and more with the broader German wissenschaft. As Sir Brian said, the ESF was not concerned with studying policy; by its activity it contributed to it.

For most practising researchers that view will probably provide some real comfort at a time when their need is not so much for science policy studies as for science policy itself. The question remains whether they can represent this interest successfully. 